\title{
The Demilitarization of Thai American Marriage Migration, 1980-2000
}

\author{
Danielle Antoinette Hidalgo • Carl L. Bankston III
}

Published online: 12 December 2010

(C) The Author(s) 2010. This article is published with open access at Springerlink.com

\begin{abstract}
In this study, we look at marriage migration patterns among Thai Americans using US Census data drawn from 5\% PUMS sets made available through the IPUMS project. Marriage is one of the most important means of migration to the USA and the overwhelming majority of Thai Americans are foreign-born women married to non-Thai men. Therefore, the sources and nature of Thai marriages to non-Thai men constitute essential elements of contemporary Thai migration and can provide valuable insight into how this key process of marriage migration can be established and maintained. Analyzing data from 1980, 1990, and 2000 , our results are consistent with the argument that much of the marriage of Thai Americans to non-Thai is historically rooted in the military connection between the USA and Thailand. However, there is evidence that the marriages of Thai women to non-Thai men have been "demilitarized." The military background of spouses has become much less compelling over the years as a predictor of the types of marriages resulting from marriage migration. Therefore, we argue that the American military presence in Southeast Asia established a pattern that continued to contribute to marriage migration even as that presence greatly diminished.
\end{abstract}

Résumé Dans cette étude, nous examinons les modèles de migration chez les Américains d'origine thaïlandaise en examinant des données de recensements américains tirées de fichiers de microdonnées à grande diffusion (échantillon de 5\%) rendus disponibles par le projet IPUMS. Le mariage est un des moyens de migration vers les États-Unis les plus importants. La grande majorité des Américains d'origine thaïlandaise sont des étrangères mariées avec des hommes qui ne sont pas d'origine thaïlandaise. Les sources et la nature de ces mariages constituent des éléments

\footnotetext{
D. A. Hidalgo $(\bowtie)$

University of California at Santa Barbara, Interdisciplinary Humanities Center, 6046 HSSB,

Santa Barbara, CA 93106-7100, USA

e-mail: daniellehidalgo@mac.com

C. L. Bankston III

Department of Sociology, Tulane University, 220 Newcomb Hall, New Orleans, LA 70118, USA

e-mail: cbankst@tulane.edu
} 
essentiels de la migration thaïlandaise contemporaine et peuvent fournir un aperçu important sur la mise en œuvre et le maintien de ce processus clé dans la migration par mariage. L'analyse de données de 1980, 1990 et 2000 indique que nos résultats correspondent avec l'argument selon lequel beaucoup des mariages entre les Américaines d'origine thaillandaise et les hommes qui ne sont pas d'origine thaillandaise tirent leurs racines dans l'histoire militaire entre les États-Unis et la Thaïlande. Toutefois, il y a lieu de croire que ces mariages ont été «démilitarisés ». Les antécédents militaires des époux sont devenus, au fil des années, moins convaincants comme variable explicative du type de mariages découlant de la migration par mariage. Nous maintenons alors que la présence militaire américaine en Asie du Sud-est a établi un modèle qui a continué à contribuer à la migration par mariage même quand cette présence diminuait de façon significative.

Keywords Immigration · Gender · Marriage · Military · Thai Americans

Mots clés immigration · genre - mariage · militaire · Américains d'origine Thaillandaise

\section{Introduction}

Family relations lie at the heart of American immigration policy. Moreover, of all family relations, the spousal relation is the basis of the greatest amount of legal admission to the U.S. Because of the central importance of marriage as a means of immigration to the U.S., the mechanics of marriage migration are especially important for immigration scholars. How, in particular, do marriages that will lead to migration take place? One answer to this question might be that marriages occur as a result of a US military presence that puts American citizens in contact with citizens of other countries. This answer may be applied to immigration from Southeast Asia, since American links to the Philippines, Vietnam, Laos, Cambodia, and Thailand have involved an American military presence in all of these countries (Bankston \& Hidalgo 2007). The military explanation for marriage migration, though, would only explain the continuation of this practice in places where a military connection exists, such as in Korea. It would not account for continuing marriage migration from countries such as Thailand, which was a major staging area for US military efforts during the Vietnam War, but which has long ceased to have significant US military bases within the country.

Contemporary Thai Americans make up a relatively new immigrant group. As shown in Fig. 1, Thai Americans have increased very rapidly in numbers since 1980. They are overwhelmingly foreign born, and almost all have arrived since the late 1960s and early 1970s. Most Asian groups are post-1965 immigrants, but the Thai were also deeply involved in the American war effort in Vietnam, Laos, and Cambodia, when Thailand was home to US military bases. Thus, the military connection offered one of the first paths for migration from Thailand to the U.S. Most contemporary Thai Americans are also women, who are overwhelmingly married to non-Thai men (see Table 1). This has continued to be the case even after the direct military link between the U.S. and Thailand ended and even though the Thai American population is much larger than in the past. Given the end of large- 
Fig. 1 Total Thai American population, and female-male composition, 1980-2000

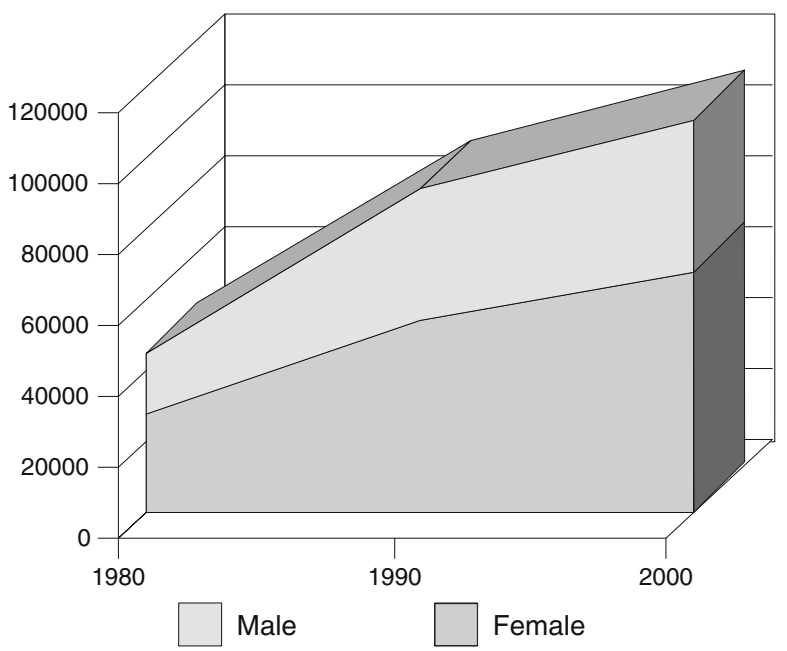

scale military involvement in Southeast Asia, the continuing pattern of marriages between Thai women and non-Thai men residing in the U.S. raises the important question of how marriage migration may have shifted from a military to a nonmilitary basis.

In this study, we analyze data from the 1980, 1990, and 2000 US censuses in order to look at marriages between Thai women and non-Thai men. We ask: (1) What are the predictors of the marriage of Thai Americans to non-Thai? (2) How can we account for the high rates of marriages to non-Thai among Thai American women, relative to Thai American men? (3) How have the predictors of Thai American marriages and the apparent characteristics of the marriages of Thai women changed over the decades?

\section{Theoretical Background: Immigrants and Marriage}

Marriage is a central issue in contemporary American immigration. Immigrants are generally admitted either under a set of seven preference categories under numerical quotas, or as special cases outside the preferences, to be granted visas without regard to numbers of individuals to be accepted. Most of those admitted under the preference system receive permission to immigrate because they have family ties to people in the U.S. (Shanks 2001).

Merali (2008) has noted that transnational marriages account for a significant portion of family-based immigration to North America. In fact, these marriages account for most immigration to the U.S. on the basis of family connections. From 1986 through 2003, for example, an average of 70\% of immigrants admitted under all preference categories were classified as family preferences. Among those who entered the U.S. through these preferences, the majority were admitted under the first preference category as spouses: $36 \%$ of all preference category immigrants and $52 \%$ of family preference immigrants were husbands or wives of residents of the U.S. Non-preference immigrants have included refugees, as well as spouses of U.S. 
Table 1 Selected characteristics of Thai Americans by sex, 1980 through 2000 (weighted cases)

\begin{tabular}{|c|c|c|c|c|c|c|}
\hline & \multicolumn{3}{|l|}{ Female } & \multicolumn{3}{|l|}{ Male } \\
\hline & 1980 & 1990 & 2000 & 1980 & 1990 & 2000 \\
\hline Percent of total & 61.2 & 58.8 & 61.2 & 38.8 & 41.2 & 38.8 \\
\hline \multicolumn{7}{|l|}{ Race/ethnicity of spouse $(\%)^{\mathrm{a}}$} \\
\hline White & 63.1 & 51.6 & 50.7 & 21.6 & 13.7 & 13.6 \\
\hline Black & 6.4 & 4.4 & 4.0 & 0.6 & 0.8 & 0.7 \\
\hline Thai & 25.9 & 36.5 & 32.4 & 64.7 & 74.0 & 69.8 \\
\hline Other Asian & 4.7 & 5.3 & 8.4 & 11.6 & 9.8 & 11.2 \\
\hline \multicolumn{7}{|l|}{ Median age } \\
\hline All & 28.0 & 35.0 & 38.0 & 20.0 & 27.0 & 29.0 \\
\hline Married & 32.0 & 40.0 & 44.0 & 33.0 & 41.0 & 46.0 \\
\hline Spouse & 33.0 & 41.0 & 47.0 & 32.0 & 38.0 & 43.0 \\
\hline Married (\%) & 49.0 & 52.4 & 51.4 & 31.1 & 38.3 & 38.0 \\
\hline Divorced or Separated (\%) & 6.8 & 8.4 & 10.2 & 3.2 & 5.0 & 6.1 \\
\hline Widowed (\%) & 1.3 & 2.5 & 3.5 & 0.0 & 0.4 & 0.7 \\
\hline Single $(\%)$ & 42.8 & 36.7 & 34.9 & 65.7 & 56.4 & 55.3 \\
\hline Under $18(\%)$ & 29.6 & 12.3 & 21.0 & 46.3 & 19.2 & 31.8 \\
\hline $18-30$ in school & 27.6 & 45.2 & 50.8 & 49.2 & 50.2 & 53.0 \\
\hline Foreign born $(\%)$ & 98.8 & 83.1 & 84.0 & 98.3 & 74.1 & 73.6 \\
\hline \multicolumn{7}{|l|}{ In USA } \\
\hline 5 years or less ${ }^{\mathrm{b}}$ & 45.2 & 21.5 & 21.5 & 46.9 & 27.4 & 24.8 \\
\hline 10 years or less ${ }^{c}$ & 87.8 & 38.8 & 34.4 & 83.5 & 48.5 & 40.4 \\
\hline Non-citizen & 63.6 & 51.1 & 45.9 & 60.0 & 50.0 & 44.7 \\
\hline Naturalized citizen & 16.4 & 27.7 & 36.3 & 11.9 & 18.0 & 26.5 \\
\hline Veteran spouse & 39.7 & 34.9 & 34.6 & 0.0 & 0.5 & 2.1 \\
\hline Non-Thai veteran spouse & 52.6 & 53.6 & 48.7 & 0.0 & 1.1 & 3.7 \\
\hline Spouse currently in military & 12.2 & 12.1 & 3.7 & 0.3 & 0.2 & 0.5 \\
\hline Non-Thai spouse currently military & 34.9 & 18.6 & 0.0 & 0.0 & 5.3 & 1.6 \\
\hline$N$ & 35,140 & 53,124 & 67,345 & 22,248 & 37,204 & 42,640 \\
\hline
\end{tabular}

${ }^{a}$ Includes only those currently married

${ }^{\mathrm{b}}$ Includes only the foreign born

${ }^{\mathrm{c}}$ Includes only the foreign born

citizens. Thus, in the period between 1986 and 2003, 35\% of non-preference immigrants and $21 \%$ of all legal immigrants to the U.S. were spouses of American citizens. Together, spouses of residents and spouses of citizens accounted for over one third of all legal immigration to the U.S., making marriage by far the most common means of legal admission to this country (U.S. Department of Homeland Security 2004).

Moreover, simply considering marriage as a direct source of immigration underestimates its importance. If someone with children marries a US citizen, the spouse becomes eligible for permanent residence and can sponsor the children under 
the second preference. By remaining in the country for 5 years and becoming a citizen, an immigrant through marriage to either a citizen or resident can sponsor unmarried children under the first preference, married children under the fourth preference, and sisters and brothers under the fifth preference (Shanks 2001).

The increase of global connections has contributed to an increase in marriage across national groups, and therefore to marriage migration, by expanding the marriage market of many individuals, and this has interacted with global inequality. Exogamy across lines of class inequality has been "globalized," with much international out-marriage involving men from countries with relatively high standards of living and women with incomes from relatively low standards of living. As worldwide transportation and communication have improved, then, men in relatively prosperous countries have been able to make contact with women in comparatively low-income countries (Bankston 1998; Nagel 2003).

Military marriages, or the "war bride" phenomenon, constitute one of the sources of marriage migration. Nagel (2003) has described the intersection of ethnicities, nationalities, and sex in warfare as the "military-sexual complex." Cross-national marriages may be one of the less exploitative forms of this complex, which often involves systematic rape and institutionalized prostitution. Since warfare is one of the ways that global connections are formed, marriage migration can begin with war and military occupation.

Military wives have arrived from many of the countries in which the U.S. has had troops, including Germany, Japan, and Korea. In some cases, a military presence has led to a country becoming a major source of female marriage migration. After the World War II, for example, the U.S. kept two large military bases in the Philippines. By one estimate, about half of all the immigrants who came to the U.S. between 1946 and 1965 arrived as wives of U.S. military personnel (Riemers 1985). Saenz et al. (1994) have pointed out that U.S. military men have married women from many other countries in Asia during the post-World War II period.

During the 1960s and 1970s, the U.S. had a major military presence in Thailand, which shares extensive borders with both Laos and Cambodia and which engaged in extensive military cooperation with the U.S. throughout the Vietnam War. Moreover, a majority of people of Thai ethnicity/ancestry in the U.S. have consistently been women, and Thai American women have consistently been married primarily to non-Thai men (Bankston and Hidalgo 2007). The history of a US military involvement in Thailand and the heavily female composition of the Thai American population suggest a military spouse origin for much of this population. However, there are problems with such an explanation.

Contrary to what we would expect if the Thai American population were largely a product of military marriage, most of the increase in this population occurred from 1980 on, after the Vietnam War, and after the end of a large-scale US military presence in Thailand. In addition, as we noted above, Thai Americans have consistently been about $60 \%$ women and most new immigrants to the U.S. from Thailand were women throughout the end of the twentieth century (Bankston and Hidalgo 2007; Cadge 2004).

The possible explanation for continuing Thai American marriage patterns that we would like to investigate in this study is that Thai American marriage has been "demilitarized." As in the case of the Philippines, we suspect that an initial military 
marriage route has been expanded into a wider civilian marriage route over the course of the late twentieth century.

\section{Data and Methods}

To look at predictors of Thai American patterns, we use data from the 1980, 1990, and 2000 IPUMS (Ruggles et al. 2003). We included Thai Americans and their spouses in our samples, attaching records of non-Thai spouses to the cases of Thai Americans. We begin with an examination of selected characteristics of Thai Americans. We present the weighted version of the data in this descriptive section because of concerns over sample selection (on the argument for using unweighted data in multivariate analysis, see Winship and Radbill 1994). Weighted data are useful for descriptive statistics because they provide approximations of the numbers in actual populations. However, we did run unweighted versions of the descriptive data and found very slight differences between weighted and unweighted results. Unless otherwise noted, our descriptive data contains all Thai Americans in the weighted versions of the IPUMS samples, in order to look at population characteristics. Among these population characteristics, we note that Thai Americans are overwhelmingly foreign born, so that their marriage patterns are those of an immigrant group.

After the descriptive data, we examine six models of predictors of being married to a non-Thai, rather than a Thai spouse for 1980, 1990, and 2000. The number of respondents in the multivariate tables is smaller than in the descriptive table because we use unweighted data in the latter. In each year, we start by looking at the odds that Thai women, rather than men, will be married to non-Thai partners, controlling for age. We then include immigration status variables, with the dichotomous foreignborn indicator coded as " 0 " for native born and " 1 " for foreign born. Our "years in the U.S." variable is coded as " 0 " for native born. We then bring in indicators of the individual's work and socioeconomic position, including whether or not the individual is in the labor force, income status, whether or not the individual has a high school degree and college degree, and whether the individual is currently in school. For the educational attainment indicators, having a "less than high school" education is the reference category. For the income status variable, we use poverty level, with 100 indicating an income at the poverty level, less than 100 indicating the percentage below the poverty level, and over 100 indicating the percentage above the poverty level in each year. As an indicator of local ethnic marriage markets for those who may have married in this country, we use the log of the estimate of the Thai population in each state for each of the 3 years.

In our final two models for each year, we bring in characteristics of spouses. In model 5, we include the spouse's occupational income score and whether or not the spouse is currently in school. By including current school status for both partners, we can examine whether endogamously married Thai in the U.S. may be those who are studying in this country. In the sixth and final model, we include a dichotomous spouse military status variable, coded as " 0 " if the spouse has not been in the military and is not currently in the military, and as " 1 " if the spouse is either a veteran or is currently serving in the military. 


\section{Analysis}

Our figures and tables were generated based on the following three empirical questions identified above: (1) What are the predictors of the marriage of Thai Americans to non-Thai? (2) How can we account for the high rates of marriages to non-Thai among Thai American women, relative to Thai American men? (3) How have the predictors of Thai American marriages and the apparent characteristics of the marriages of Thai women changed over the decades? Reviewing the top of Table 1, Thai American women outnumber Thai American men across all 3 years of analysis. Further, as evident in Fig. 2, Thai American women have consistently married non-Thais to a far greater extent than Thai men. In 1980, for example, Thai women outnumbered Thai men by $22.4 \%$. In 2000 , there were, again, $22.4 \%$ more women than men. Interestingly, however, this difference dropped in 1990, where there were only $17.6 \%$ more women than men, indicating that the rate of growth of the male Thai American population increased between 1980 and 1990. Looking at the race/ethnicity of spouses, Thai American women have consistently shown much higher percentages of marriages to white men. In 1980, 63.1\% of Thai women were married to white men (69.5\% were married to both white and Black men). As the years progressed, however, the numbers decreased to $51.6 \%$ in 1990 and $50.7 \%$ in 2000. Thai men, in contrast, consistently tend to be married to Thai women, either by bringing spouses with them from Thailand or by finding co-ethnic spouses in the U.S. Thai men's exogamous percentages are 33.8 in 1980, 24.3 in 1990, and 25.5 in 2000. Since the non-Thai cannot be immigrants from Thailand and since Thai in the U.S. overwhelmingly are immigrants, we can conclude that most Thai women in the U.S. are immigrants who either come to the U.S. and marry outside their own groups or who arrive in this country by means of marriage. The importance American immigration policy gives to marriage as a basis of migration (discussed above) strongly indicates that marriage is a critical source of migration for women from Thailand. By contrast, the fact that most Thai men are married to women of their own group suggests that marriage is much less important as a basis of migration for the men.

Fig. 2 Estimated numbers of Thai American women with non-Thai and Thai husbands, 1980-2000

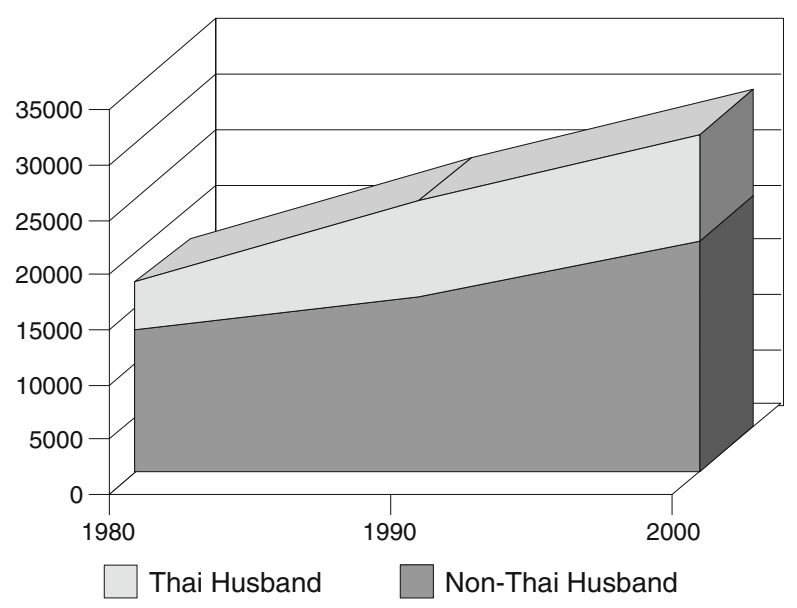


Looking at the age characteristics of our sample, men, on average, tend to be younger than women and Thai American women's average age increased across the 3 years. Further, as evident among the Thai Americans who are married, Thai women's and men's average age increases even more. Among all of the respondents, Thai American women, on average, are more likely to be married than Thai American men as nearly half or more of these women are married while about $31 \%$ to $38 \%$ of Thai American men are married across all years of analysis.

In terms of education, the numbers have increased for both men and women, but they substantially increased for women. Only 27.6\% of Thai American women (ages 18-30) were in school in 1980 while in 2000, half of these women were in school (50.8). Half of the Thai men have consistently been in school throughout the years.

The majority of Thai Americans (men and women) are foreign born, as we have mentioned. While the percentages are a bit higher for women (about 10\% more as the years progress), the overall percentages of foreign-born people for both men and women are over $70 \%$. Including only the foreign-born respondents, percentages of Thai American men and women who have been in the U.S. for 10 years or less decreased drastically since 1980. In 1980, 87.8\% of Thai American women and $83.5 \%$ of Thai American men had been in the U.S. for 10 years or less; in 2000, the figure has dropped sharply, as $34.4 \%$ of Thai American women and $40.4 \%$ of Thai American men have lived in the U.S. for 10 years or less. Reviewing Fig. 1, we can see that these percentages are influenced by the increase in the overall population of Thais in the U.S. As Fig. 1 shows, the Thai American population has consistently increased since 1980. According to estimates of Summary File 4 of the 2000 Census, the best source of population information on specific groups, the population was only 45,279 in that year, but by 2000 the population had reached 110,851 (these numbers differ slightly from estimates of the weighted IPUMS data; U.S. Census Bureau 2003). Thus, the comparatively small population of 1980 was composed almost entirely of newcomers, while the larger populations of the succeeding decades included arrivals from earlier years and the children of those arrivals. Further, as we saw at the top of Table 1, Thai American women have always outnumbered Thai American men, making up an average of $60 \%$ of the total population throughout these years.

Even though the percentage of non-citizen Thais has dropped for both women and men, non-citizens still make up about half of the Thai American population. Naturalized citizenship status has, however, doubled for women and men (women and men in 1980 were $16.4 \%$ and $11.9 \%$, respectively, and in 2000 , naturalized women and men made up $36.3 \%$ and $26.5 \%$ of the total).

Highlighting the main topic of this research, the "spouse a veteran" category is far more substantial for women than it is for men. In 2000, 34.6\% of Thai American women had spouses who were veterans, while for Thai American men, only $2.1 \%$ were married to veterans. Clearly, this has a lot to do with gender and the military, but it also indicates that many of the exogamously married Thai women had married either current or former military personnel. The next variable, "non-Thai spouse a veteran," again, indicates a telling marriage pattern for Thai American women and men. Thai men's percentages were consistently low (being only $0 \%$ in 1980) while, for women, $52.6 \%$ in $1980,53.6 \%$ in 1990 , and $48.7 \%$ in 2000 were married to nonThai veterans. That is, if a woman's spouse was non-Thai, there was about a $50 \%$ 
chance that the spouse, was, in fact, a veteran. Next, as indicated in the "spouse currently in the military" variable, these percentages decreased over the years, falling nearly $10 \%$ by the year 2000 to $3.7 \%$. Of non-Thai spouses currently in the military, the figures slightly change; non-Thai spouses of Thai American women are $34.9 \%$ in $1980,18.6 \%$ in 1990, and $0 \%$ in 2000. After the end of the Vietnam War and the end of the direct military link between the U.S. and Thailand, it makes sense that marriages with veterans would decline steadily over time.

In the remaining sections, we review Tables $2-4$, outlining the various odds and standard errors of predictors of marriage to non-Thai spouses among Thai Americans for the years 1980, 1990, and 2000. As mentioned above, we use unweighted cases in these analyses, so that the values of $N$ in the tables reflect numbers of cases in the sample, rather than the approximations of the population in Table 1 . Model 1 in Table 2 indicates a significant difference between men and women; Thai women are far more likely to have non-Thai spouses than Thai men and as age increases, the likelihood of marrying exogamously decreases. In model 2, neither being foreign born nor years in the U.S. is significantly related to exogamy, nor do these migration variables affect the likelihood that Thai women, rather than Thai men, will be married to non-Thai partners. Model 3, however, shows a substantial change in the association between sex and out-marriage. The odds of Thai women marrying nonThai men continue to be statistically significant, but decreases substantially when labor force participation, income status, HS graduate, college graduate, and in school are added to the model. Of these additional variables, in the labor force, HS graduate, and college graduate are significant. The variable "in the labor force," for example, has a significant odds ratio of 0.65 , indicating that Thai Americans who were in the labor force were less likely than those not in the labor force to be married to non-Thai. Further, those respondents who were high school graduates in 1980 were also less likely than non-graduates to be married outside the group. College graduates were also less likely than people without high school educations to be married to non-group members, but less so than those who only had high school educations. Most interesting here, however, is the sharp decrease in the gender variable; as soon as these variables were added, Thai women marrying nonThai men decreased quite substantially $(\operatorname{EXP}(B)=5.52$ in model 1 and 2.43 in model 3).

Adding the log Thai population in model 4, we wanted to see whether or not the probability of Thais living in close proximity was related to the ethnicity of marriage partners. As the results show, there is a significant effect. Those who live closer to each other do tend to be married to non-Thai partners $(\operatorname{EXP}(B)=0.67)$. In the final two models, 4 and 5, we added the spouse occupational score, spouse in school, and, finally, spouse military status variables. In model 5, the two variables were not significant but they slightly raised the odds for the gender variable. Finally, in model 6 , the final significant result of 138.71 for spouse military status indicates that veteran/military status did, indeed, have a very large relationship to the probability that Thai American women would be married to non-Thai in 1980. Statistically, there are two explanations for this large impact: (1) low socioeconomic status and (2) spouses were either formerly or currently in the military. Hence, in 1980, these were two significant explanations for the high rate of the marriage of Thai American women to men who were not Thai. 


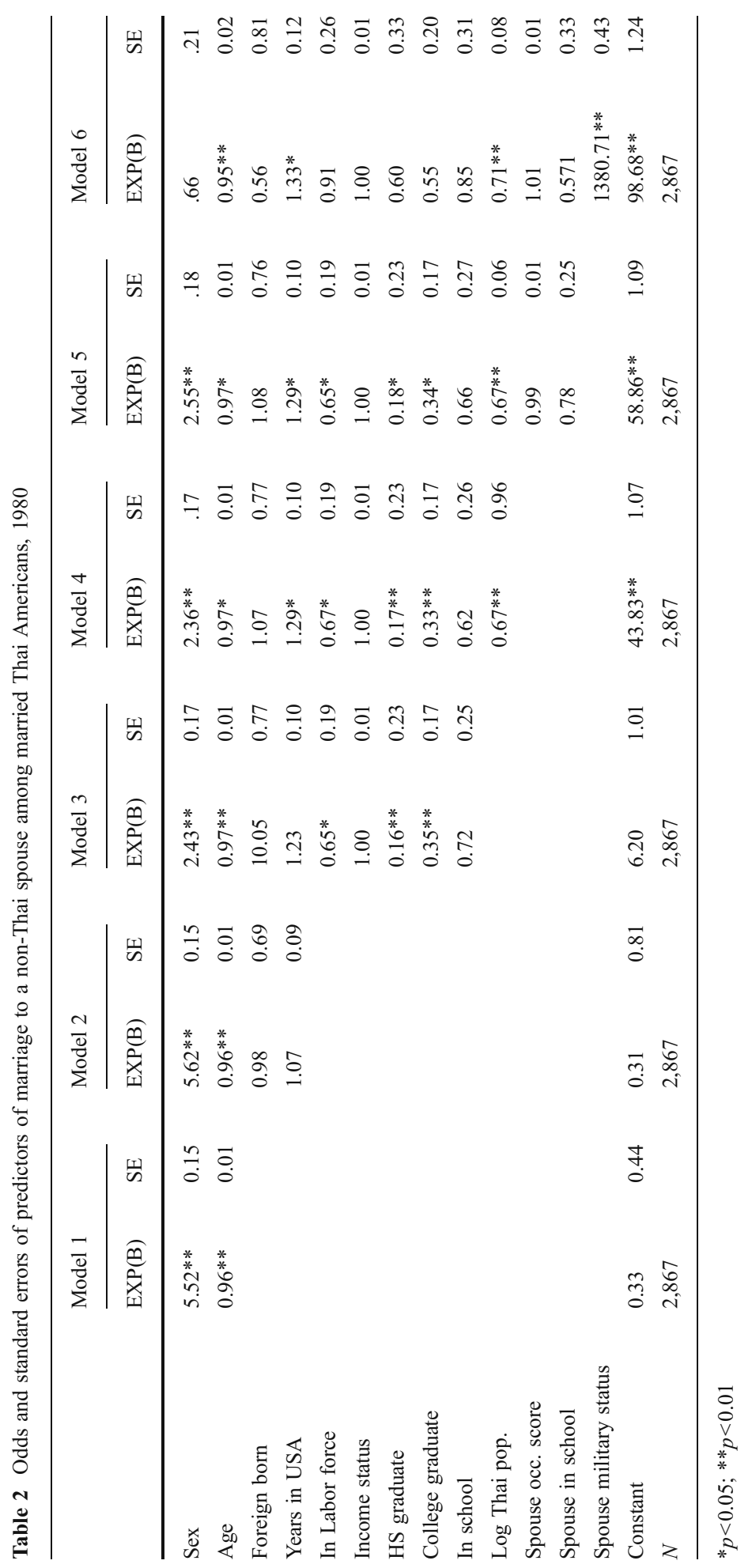


Table 3 begins with a slightly lower significant gender variable result $(\mathrm{EXP}(\mathrm{B})=$ 4.67). Again, as in Table 2, foreign born and years in the U.S. do not influence gender and age, although years in the U.S. is significant; according to the results for 1990, more time in the U.S. raised the probability that Thai Americans would be married to non-Thai. Gender does lower a bit in model 3, as it similarly did in the same model in Table 2, and, again, in model 4, Thais in close proximity tend to have an even higher rate of marriage to other Thais for this year. Model 5 indicates that spouse's occupational score is significant and that women, again, are more likely than men to be married outside of this still primarily immigrant group. Also, the higher occupational score of one's spouse $(\operatorname{EXP}(B)=0.98)$ indicates that higher occupational spousal score is associated with a decreased likelihood of marrying out. Finally, in model 6, spouse military status, while still significant and quite high, decreases significantly; the result is not nearly as dramatic as our results in 1980. There is still an association between marriage to a non-Thai and the military status of a spouse, with Thai women having a higher association than Thai men, but this association is far less than what was revealed in Table 2. Hence, the association between exogamy and having a military spouse weakened in this 10 -year period.

Table 4 begins with similar results, but as evident in model 2, being foreign-born is now a statistically significant predictor of being married to a non-Thai. To understand this, we can refer back to the frequencies in Table 1. In 1980, virtually all Thai men and women were foreign born. Only by 2000 was the still relatively small number of Thai people born in the U.S. large enough to be related to marriage partners. The positive relationship between length of time in the U.S. and being married to a non-Thai can logically reflect two processes. First, those who live in the U.S. longer may be more likely to meet and marry non-Thai than new arrivals. Second, those who arrive by means of marriage migration to non-Thai are likely to have arrived in earlier years. Again, log Thai population indicates that there is a tendency for Thais in close proximity to marry other Thais. In model 5, the gender variable changes very little, even with the addition of spouses' occupational score and spouse in school. Model 6 offers the most telling result in our study. Marriage to a military veteran was still a significant predictor of marriage to a non-Thai, but it was a much weaker predictor than in earlier years. Moreover, marriage to a veteran no longer statistically accounted for the greater likelihood that a woman would be married to a non-Thai, as it had in the earlier years. By 2000, the marriages of women in this immigrant group to men who did not come from the home country had been "demilitarized." Marriage outside the national origin group, a primary source of marriage migration, connected much less to previous military service than in earlier years. However, Thai women continued to be more likely than Thai men to marry outside the national origin group, even as marriages with former American soldiers accounted for fewer of these unions.

\section{Conclusion}

Our results are consistent with the argument that much of Thai American marriage migration is historically rooted in the military connection between the U.S. and Thailand, and that the particularly high rate of marriage to people outside the 


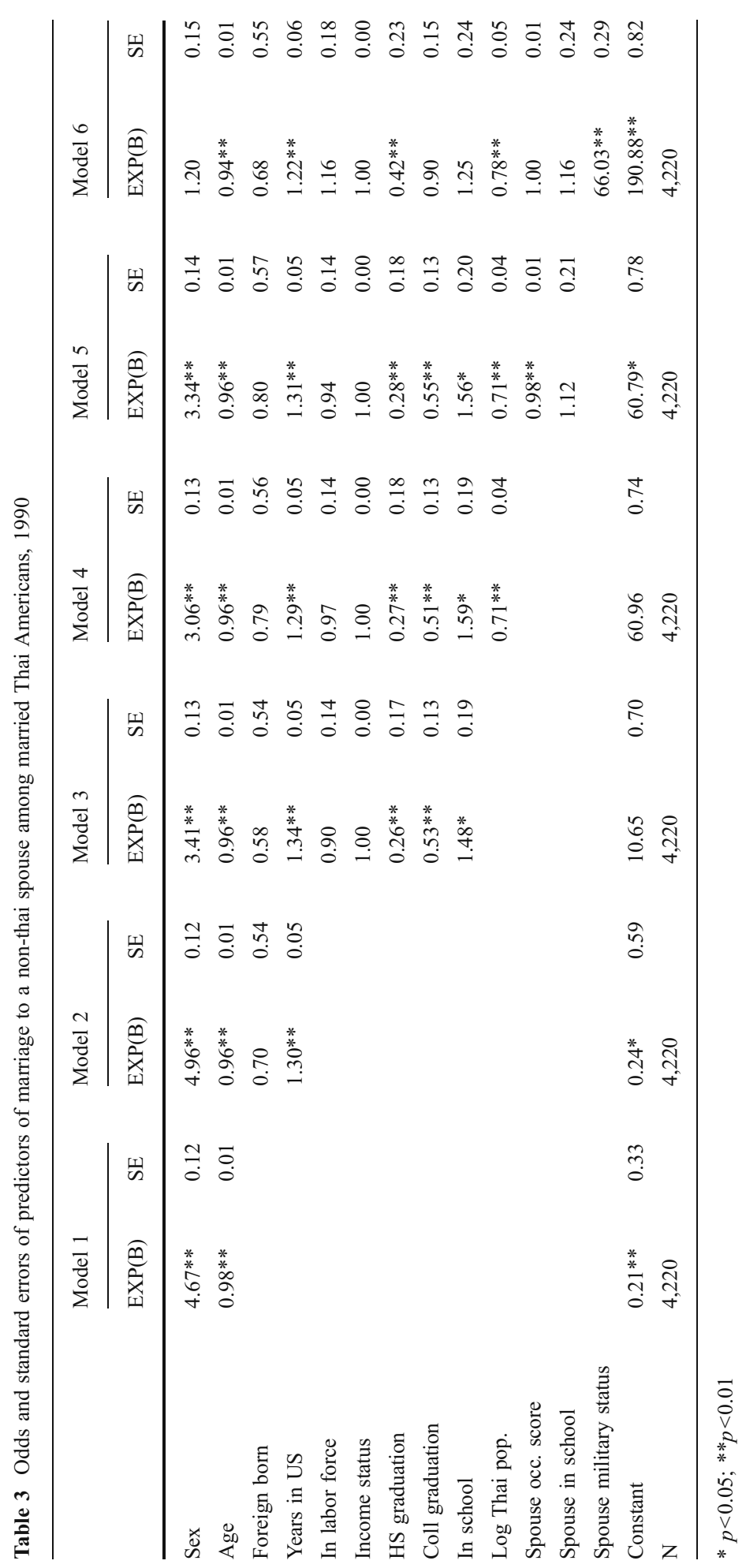




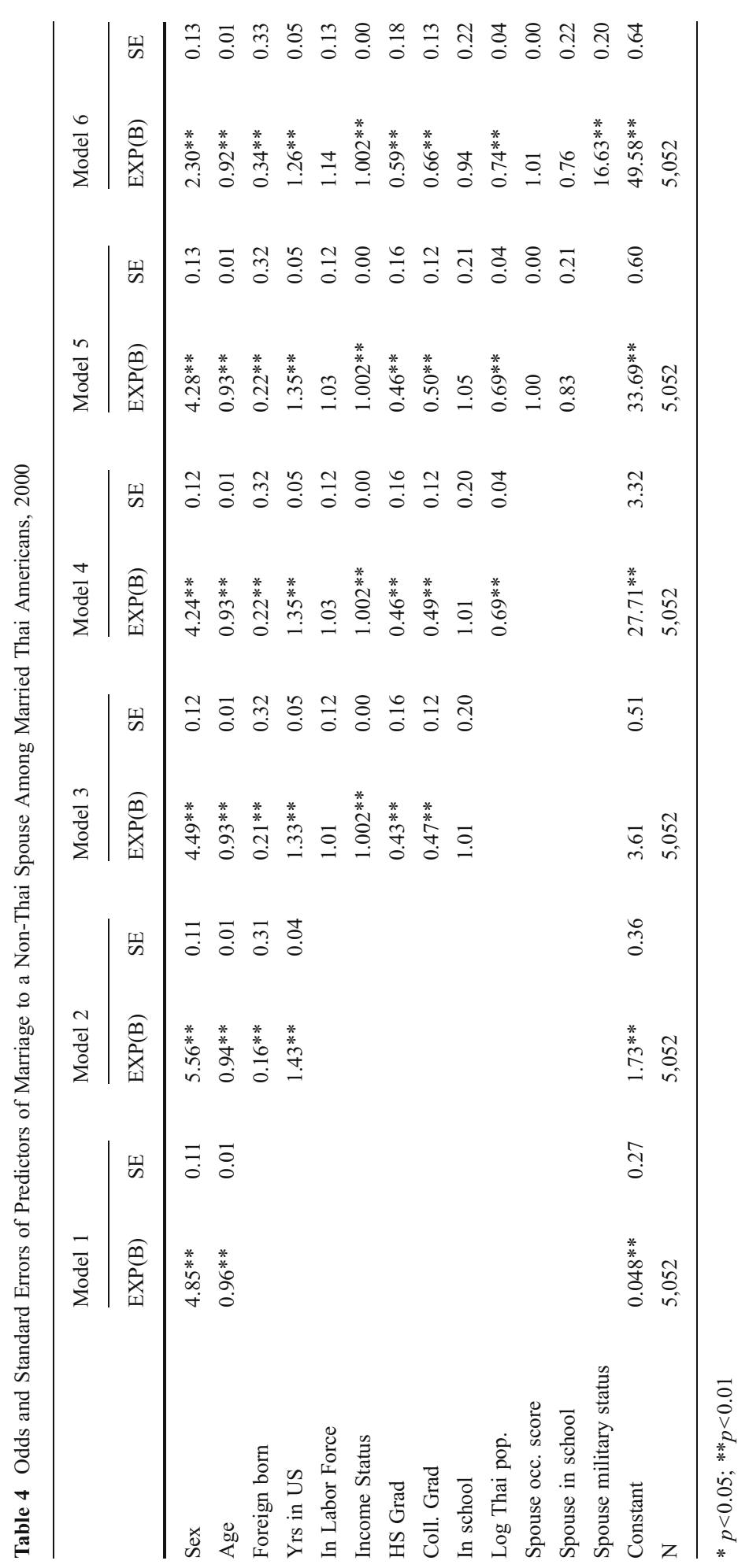


national origin group, as a basis for marriage migration, among Thai American women is historically linked to this military connection. It is not surprising that marriage contacts between Thai people and those from the U.S. were connected to the American military presence during the Vietnam War period. However, while Thai women have continued to show high rates of marriage to men who were not from Thailand, there is evidence that this probability has been "demilitarized." The military background of spouses has become much less compelling over the years as a predictor of marriages to non-Thai, and it has diminished as a statistical accounting for unions of Thai women with men who were not from their national origin group.

Our data do not enable us to make observations about how marriages between Thai American women and others are formed. We do not know how many of them married here, rather than in Thailand, although we can reasonably infer that marriage is a major avenue for migration from Thailand by the critical role of marriage in migration that we have discussed above. Moreover, we do not know, from these data, how Thai women and non-Thai men find each other as mates, particularly in Thailand prior to migration, or what they may find desirable about their marriage combinations. One early reader of this study has suggested to us that role-modeling and inter-group processes could play a part. As increasing numbers of Thai women have married non-Thai men, these women could provide role models for other Thai ethnicity women as well as for non-Thai men seeking spouses and also promote inter-group contact. Because US military involvement has set a pattern of marriages, women in Thailand have come to see marriage to American men as a possibility and as a route for migration. American men, similarly, have learned to see Thailand as a source of partners and this pattern has continued after the military connection between the two countries has diminished. Transnational unions establish links between these two countries, creating global social networks that continue and grow. Both economic differences between Thailand and the U.S. and American family reunification policies contribute to maintaining and strengthening the formation of marriages as a means of international migration. Until those economic differences disappear or until U.S. immigration policies cease to place such a heavy emphasis on marriage, we can expect that the Thai American marital patterns first established by military involvement will continue as the Vietnam War passes into historical memory.

Open Access This article is distributed under the terms of the Creative Commons Attribution Noncommercial License which permits any noncommercial use, distribution, and reproduction in any medium, provided the original author(s) and source are credited.

\section{References}

Bankston, C. L., III. (1998). Mail order brides. In C. L. Bankston III \& R. K. Rasmussen (Eds.), Encyclopedia of family life. Pasadena, California: Salem Press.

Bankston, C. L., III, \& Hidalgo, D. (2007). Southeast Asia: Laos, Cambodia, Thailand. In M. C. Waters \& Ueda Reed (Eds.), The New Americans. Cambridge: Harvard University Press.

Cadge, W. (2004). Heartwood: The first generation of Theravada Buddhism in America. Chicago: University of Chicago Press.

Merali, N. (2008). Theoretical frameworks for studying female marriage migrants. Psychol Women Q, 32, 281-9.

Nagel, J. (2003). Race, ethnicity, and sexuality: intimate intersections, forbidden frontiers. New York: Oxford University Press. 
Riemers, D. (1985). Still the golden door: The third world comes to America. New York: Columbia University Press.

Ruggles, Steven, Matthew Sobek, M., et al. (2003). Integrated public use microdata series: version 3.0 (1\% and 5\% PUMS samples). Minneapolis: Historical Census Projects, University of Minnesota.

Saenz, R., Hwang, S.-S., \& Aguirre, B. E. (1994). In search of Asian war Brides. Demography, 31, 549559.

Shanks, C. (2001). Immigration and the politics of American Sovereignty, 1880-1990. Ann Arbor: University of Michigan Press.

U.S. Census Bureau (2003) 2000 Census of population and housing-summary file 4-sample data. Electronic files retrieved and analysed December 2004 at www.factfinder.census.gov.

U.S. Department of Homeland Security. (2004). Yearbook of immigration statistics: 2004. Washington, D. C.: U.S. GPO.

Winship, C., \& Radbill, L. (1994). Sampling weights and regression analysis. Sociol Methods Res, 23, $230-257$.

Danielle Antoinette Hidalgo, Ph.D., specializes in gender, sexuality, embodiment and globalization. In addition to numerous authored and co-authored journal articles and book chapters, she recently co-edited (with Kristen Barber) Narrating the Storm: Sociological Stories of Hurricane Katrina. She has been the recipient of numerous awards, including the UC President's Dissertation-Year Fellowship, the Mid-South Sociological Association's Graduate Student Paper of Distinction Award, and the Stanford M. Lyman Dissertation Scholarship.

Carl L. Bankston III is a professor and the chairman of the Department of Sociology and a co-director of the Asian Studies program at Tulane University. He is author of seven books, the most recent of which is Public Education-America's Civil Religion: A Social History (Teachers College Press, March 2009), editor of ten books, and has published over 100 journal articles and book chapters. His areas of research include immigration, Asian studies, and sociology of education. 